\title{
Manajemen Kolaboratif Dalam Penanggulangan Bencana Daerah Di Kabupaten Banjarnegara
}

\section{Herlina Wahyu Tri Widyaningsih}

Mahasiswa Program Studi Magister Administrasi Publik, FISIP, Universitas Jenderal Soedirman e-mail: herlinawahyutriwidyaningsih@yahoo.co.id

\begin{abstract}
Abstrak
Penelitian ini bertujuan untuk menganalisis faktor-faktor yang menghambat dan mendukung manajemen kolaboratif penanggulangan bencana di Kabupaten Banjarnegara serta strategi yang dilakukan untuk mengatasi hambatan tersebut. Penelitian ini menggunakan metode pendekatan kualitatif dengan tipe deskriptif. Desain penelitian ini adalah studi kasus. Pemilihan informan menggunakan teknik purposive sampling, pertimbangan yang digunakan adalah informan tersebut dapat menjadi nara sumber yang memahami betul tentang manajemen kolaboratif penanggulangan bencana di Kabupaten Banjarnegara sehingga dapat memberi informasi tentang berbagai hal yang berkaitan dengan permasalahan penelitian. Informan utamanya adalah Kepala BPBD dan Kepala Bagian Pelaksana BPBD, Dinas Kesehatan, Sekda Kabupaten Banjarnegara, DPRD Kabupaten Banjarnegara Komisi D, dan Kepala Kantor Dinas Sosial. Informan pendukung adalah ketua oganisasi masyarakat. Pengumpulan data menggunakan metode wawancara, observasi dan dokumentasi. Data hasil penelitian dianalisis menggunakan model interaktif. Hasil penelitian memperoleh kesimpulan: 1) Manajemen kolaboratif di Kabupaten Banjarnegara secara keseluruhan belum sepenuhnya berjalan secara efektif dan efisien, dan belum sepenuhnya dapat memuaskan masyarakat secara keseluruhan. Pada tahap response sudah berjalan cukup baik, pada tahap recovery berjalan cukup baik, dan tahap developing berjalan cukup baik namun belum selesai karena terkendala pembebasan tanah warga. BPBD dapat berkolaborasi dengan berbagai unsur lembaga pemerintah dan lembaga non pemerintah dalam rangka mencapai tujuan bersama yaitu meminimalisir jumlah korban dan resiko dampak bencana, 2) Faktor pendukung adalah adanya komunikasi, komitmen dan saling memahami diantara para stakeholder yang direalisasikan dengan kerjasama dan kesadaran dari semua elemen akan tugas dan tanggungjawab masing-masing sehingga faktor penghambat berupa keterbatasan SDM, peralatan dan anggaran dapat teratasi dengan adanya kolaborasi tersebut. Dengan demikian maka dapat dikatakan bahwa manajemen kolaboratif dalam penanggulangan bencana di Kabupaten Banjarnegara merupakan manajemen bencana yang solvable bagi penanganan bencana di Kabupaten Banjarnegara yang memiliki kerentanan dan potensi bencana dari beberapa aspek, yaitu aspek geografis, klimatologis, geologi, dan sosial demografis.

\section{Kata Kunci: Manajemen Kolaboratif, Penanggulangan Bencana, Faktor Pendukung dan Penghambat.}

Abstract
This study aims to analyze the factors that supporting factors and inhibiting
factorsin in collaborative management of disaster management in Banjarnegara
District and strategies undertaken to overcome these obstacles. This research uses a
qualitative approach with descriptive type. The design of this research is a case
study. The selection of informants uses purposive sampling techniques, the
consideration used is that the informant can be a resource person who understands
very well about collaborative management of disaster management in Banjarnegara
District so that it can provide information about various matters relating to research
problems. The main informants were the Head of the BPBD and the Head of the
Implementing Section of the BPBD, the Health Service, the Regional Secretary of the
Banjarnegara District, the Regional Representative Council of the Banjarnegara


Commission D, and the Head of the Office of the Social Service. Supporting informant is the head of community organization. Data collection using interviews, observation and documentation. Research data were analyzed using an interactive model. The results of the study concluded: 1) Collaborative management in Banjarnegara District as a whole has not been fully effective and efficient, and has not been able to fully satisfy the community as a whole. At the response stage it has been going quite well, the recovery stage is going pretty well, and the developing stage is going pretty well but it hasn't finished yet due to constrained land acquisition for residents. BPBD can collaborate with various elements of government agencies and nongovernmental institutions in order to achieve a common goal which is to minimize the number of victims and the risk of disaster impacts, 2) Supporting factors are the existence of communication, commitment and mutual understanding among the stakeholders which is realized by collaboration and awareness of all elements of their respective duties and responsibilities so that the limiting factors in the form of limited human resources, equipment and budget can be overcome by the collaboration. Thus it can be said that collaborative management in disaster management in Banjarnegara District is a disaster management that is solvable for disaster management in Banjarnegara District which has vulnerability and potential disasters from several aspects, like geographical, climatological, geological, and social demographic aspects.

Key Words: Collaborative Management, Disaster Management, Supporting Factor and Inhibit Factor.

\section{PENDAHULUAN}

Setiap organisasi, baik organisasi pemerintah maupun organisasi swasta membutuhkan manajemen agar dalam pencapaian tujuannya dapat berjalan dengan efektif dan efisien. Sebagaimana definisi manajemen yang dikemukakan oleh Daft (2010) bahwa manajemen merupakan pencapaian tujuan-tujuan organisasional secara efektif dan efisien. Pada beberapa kondisi, pencapaian suatu tujuan kadang tidak dapat dilakukan sendiri oleh suatu organisasi karena adanya beberapa keterbatasan, seperti keterbatasan sumber daya, keterbatasan informasi, waktu dan teknologi. Upaya untuk menyelesaikan masalah ini alternatifnya adalah dengan cara menciptakan solusi dalam kondisi keterbatasan, yaitu melakukan kolaborasi. Kolaborasi merupakan upaya penyatuan berbagai pihak untuk mencapai tujuan yang sama (Harley dan Bisman, 2010). Di dalam kolaborasi membutuhkan kerjasama dari berbagai aktor baik individual maupun organisasi demi tercapaianya tujuan bersama. Agar kolaborasi dari berbagai unsur tersebut dapat berjalan terarah dan terorganisir dengan baik maka diperlukan manajemen kolaboratif.

Manajemen kolaboratif adalah suatu proses kerjasama saling membantu untuk mendapatkan solusi atau menyelesaikan tugas atau pekerjaan yang dilakukan secara sistematis antar individu atau organisasi dari proses perencanaan, pengorganisasian, pelaksanaan, dan pengawasan dalam rangka mencapai tujuan bersama. Ditegaskan oleh Nawawi (2008) bahwa kolaborasi adalah usaha untuk mencapai tujuan bersama yang telah ditetapkan melalui pembagian tugas/pekerjaan, tidak sebagai pengkotakan kerja akan tetapi sebagai satu kesatuan kerja, yang semuanya terarah pada pencapaian tujuan. Manajemen kolaboratif juga digunakan 
dalam penanggulangan bencana di Indonesia. Terkait dengan manajemen kolaboratif dalam penanggulangan bencana, pemerintah membentuk badan penanganan bencana yang diatur dengan Keputusan Presiden Nomor 3 Tahun 2001, yaitu di tingkat pusat dibentuk Badan Koordinasi Nasional Penanggulangan Bencana dan Penanganan Pengungsi (BAKORNAS PBP), sedangkan pada daerah provinsi dibentuk Satuan Koordinasi Pelaksana Penanggulangan Bencana dan Penanganan Pengungsi (SATKORLAK PBP), kemudian di tingkat kabupaten/kota dibentuk Satuan Pelaksana Penanggulangan Bencana dan Penanganan Pengungsi (SATLAK PBP). Berdasarkan ketetapan presiden tersebut maka penanggulangan bencana di seluruh wilayah Indonesia menggunakan manajemen kolaboratif, termasuk di kabupaten Banjarnegara. Kabupaten Banjarnegara merupakan salah satu wilayah di Provinsi Jawa Tengah yang memiliki kerentanan terjadinya bencana, seperti gempa, angin kencang, kebakaran, banjir, dan tanah longsor.Berdasar dokumen Badan Penanggulangan Bencana Daerah (BPBD) Kabupaten Banjarnegara, selama tahun 2017 terdapat kejadian bencana sebagai berikut:

Tabel 1. Bencana di Kabupaten Banjarnegara tahun 2017

\begin{tabular}{lc|lc}
\hline \multicolumn{1}{c|}{ Jenis bencana } & Jumlah perisitiwa & \multicolumn{1}{c}{ Korban } & Jumlah \\
\hline Tanah Longsor & 112 & Rumah rusak Berat & 51 \\
Banjir & 3 & Rumah rusak Sedang & 100 \\
Angin Kencang & 20 & Rumah rusak Ringan & 108 \\
Gempa & 2 & Rumah Terancam & 186 \\
Kebakaran & 18 & Meninggal Dunia & 2 \\
Erupsi & 2 & Luka - Luka & 33 \\
\hline \multicolumn{2}{c}{ Jumlah } & \multicolumn{1}{c}{ Jumlah } & $\mathbf{4 8 0}$ \\
\hline \multicolumn{2}{c}{ Jumlah kerugian } & $\mathbf{R p ~} \mathbf{8 . 3 9 7 . 1 0 5 . 0 0 0}$ \\
\hline
\end{tabular}

Sumber: BPBD Kabupaten Banjarnegara, 2018

Data pada tabel di atas menunjukkan bila kabupaten Banjarnegara merupakan wilayah dengan kejadian bencana yang dapat dikatakan luar biasa, karena dalam kurun waktu 1 tahun bisa terjadi 157 bencana dengan nilai kerugian sebesar Rp 8.397.105.000,-. Bencana tanah longsor merupakan bencana yang paling sering terjadi, karena sebagian besar wilayah di Kabupaten Banjarnegara merupakan perbukitan dengan jenis tanah yang mudah mengalami longsor bila tergerus air hujan. Kondisi ini sangat memerlukan manajemen penanggulangan bencana yang solvable bagi pemerintah daerah sendiri dan juga masyarakat yang terdampak bencana.

Bencana ataupun bencana alam yang terjadi di suatu daerah biasanya mengakibatkan korban jiwa, mengalami luka berat dan ringan kerusakan fasilitas umum dan kerusakan lingkungan. Korban jiwa, mengalami luka berat atau luka ringan membutuhkan bantuan medis dan layanan kesehatan, membutuhkan kerjasama dengan rumah sakit atau poli kesehatan terdekat dan dinas sosial. Kerusakan fasilitas umum seperti kerusakan jaringan listrik, jaringan air bersih, gedung perkantoran, jalan, jembatan bahkan rumah penduduk, membutuhkan perbaikan yang dikerjakan oleh ahlinya oleh karena itu membutuhkan kerjasama dengan instansi atau dinas terkait, seperti PDAM, Dinas PU, Dinas Ciptakarya, PLN. Di samping itu, pada kasus tertentu membutuhkan bantuan lembaga pendidikan atau lembaga swadaya masyarakat 
yang memiliki keahlian yang dibutuhkan atau tenaga ahli dalam melakukan penanganan bencana. Oleh karena itu, bencana yang berdampak pada semua aspek kehidupan manusia tidak bisa ditanggulangi sendirian oleh satu lembaga, tetapi membutuhkan kolaborasi atau kerjasama dengan berbagai pihak terutama instansi pemerintah terkait.Seperti penanganan bencana tanah longsor di dusun Jemblung ditangani oleh banyak pihak terkait, untuk evakuasi korban bekerjasama dengan TIM SAR, masyarakat, dinas PU, dan rumah sakit terdekat, untuk memulihkan kondisi sosial ekonomi para korban BPBD Banjarnegara yang bekerja sama dengan Kementerian Pekerjaan Umum dan Perumahan RakyatKabupaten Banjarnegara.

Penanganan bencana di Kabupaten Banjarnegara seperti yang sudah dipaparkan di atas menunjukkan bila sudah dilakukan secara kolaboratif sebagaimana yang diatur oleh pemerintah, dimana penanggulangan bencana di Indonesia menggunakan manajemen kolaboratif, mulai dari pemerintah pusat sampai pemerintah daerah. Platform nasional penanganan bencana dan pengurangan resiko bencana dilakukan secara kolaborasi yaitu oleh para pemangku kepentingan yang meliputi pemerintah, lembaga pemerintah dan non pemerintah, masyarakat sipil, dan akademisi (Kusumasari, 2014). Manajemen kolaboratif penanggulangan bencana ini sudah diimplementasikan di semua wilayah Indonesia.

Penanggulangan bencana di Kabupaten Banjarnegara selama ini juga memiliki permasalahan yang hampir sama yaitu keterbatasan jumlah SDM, keterbatasan jumlah dan sumber anggaran dan keterbatasan peralatan untuk mengevakuasi korban, rehabilitasi dan pemulihan wilayah serta sarana prasarana terdampak bencana. Dengan adanya manajemen kolaboratif dalam penanggulangan bencana diharapkan dapat mengatasi permasalahan tersebut. Berdasarkan informasi dan pengamatan peneliti saat studi awal, penanggulangan bencana di kabupaten Banjarnegara yang dilakukan secara kolaborasi belum maksimal karena ada kendala teknis. Misalnya dalam penyaluran bantuan kepada korban bencana kurang merata atau terlambat karena belum terkoordinir dengan baik atau karena terkendali tekni seperti saat bencana longsor di dusun Jemblung Kecamatan Karangkobar, bantuan untuk pengungsi sempat tersendat beberapa hari karena ada jalur yang tertutup longsoran namun pada akhirnya dapat diatasi dalam waktu 4 hari kemudian (Suriyanto, 2014). Di sisi lain, penanggulangan bencana di Kabupaten Banjarnegara yang dilakukan secara kolaborasi cukup baik khususnya dalam pemulihan akibat bencana. Misalnya dalam penanganan dan pemulihan bencana tanah longsor di dusun Jemblung, pihak BPBD kabupaten Banjarnegara berkolaborasi dengan institusi terkait dan masyarakat akademik, yaitu KemenPUPera dan Dinas Pekerjaan Umum, mahasiswa S2 MPWK Undip (Sulistyo, 2015).

Berdasarkan angka indeks kepuasan masyarakat atas kinerja badan penanggulangan bencana daerah (BPBD) dalam menangani bencana, yaitu pada tahun 2017 sebesar 78,60 dan tahun 2018 meningkat menjadi 81,41 (BPBD Kabupaten Banjarnegara, 2017 \& 2018), 
menunjukkan bahwa tingkat kepuasan masyarakat pada penanggulangan bencana yang dilakukan secara kolaboratif yang dikoordinir oleh badan penanggulangan bencana daerah (BPBD) kabupaten Banjarnegara adalah sedang. Dengan demikian dapat dikatakan bahwa pelaksanaan manajemen kolaboratif penanggulangan bencana di kabupaten Banjarnegara belum maksimal karena tingkat kepuasan masyarakat pada penanggulangan bencana secara kolaboratif belum tinggi. Oleh karena itu perlu dilakukan penelitian penanggulangan bencana yang dilakukan secara kolaborasi atau manajemen kolaboratif penanggulangan bencana di kabupaten Banjarnegara, untuk menggali informasi lebih dalam tentang bagaimana manajemen kolaboratif penanggulangan bencana di Kabupaten Banjarnegara, faktor-faktor yang menghambat dan yang mendukungnya. Sehingga dapat diambil langkah-langkah untuk peningkatan dan perbaikan dalam manajemen kolaboratif penanggulangan bencana di Kabupaten Banjarnegara di masa mendatang. Penelitian ini dilakukan untuk mengkaji lebih dalam tentang respons dan keterlibatan para stakehoder dalam kolaborasi manajemen penanggulangan bencana di Kabupaten Banjarnegara.

\section{TINJAUAN PUSTAKA}

\section{Manajemen Kolaboratif}

Schrage dalam Harley dan Bisman (2010) mengemukakan bahwa kolaborasi merupakan upaya penyatuan berbagai pihak untuk mencapai tujuan yang sama. Kolaborasi membutuhkan berbagai macam aktor baik individual maupun organisasi yang bahu membahu mengerjakan tugas demi tercapaianya tujuan bersama. Berdasarkan berbagai definisi tentang kolaborasi di atas, maka dapat dipahami bila individu atau organisasi memiliki keterbatasan dalam mencapai suatu tujuan, dengan adanya kebutuhan yang sana yaitu mencapai tujuan yang sama sehingga individu atau organisasi melakukan kolaborasi atau kerjasama dengan individu atau organisasi lain. Menurut Raharja (2008) kolaborasi pada hakikatnya adalah suatu kerjasama yang dilakukan antar organisasi untuk mencapai tujuan bersama yang tidak mungkin atau sulit dicapai apabila dilakukan secara individual atau mandiri. Berdasarkan pada pengertian manajemen dan pengertian kolaborasi yang sudah dipaparkan diatas, maka dapat ditarik suatu kesimpulan tentang pengertian manajemen kolaboratif adalah suatu proses kerjasama saling membantu untuk mendapatkan solusi atau menyelesaikan tugas atau pekerjaan yang dilakukan secara sistematis antar individu atau organisasi dari proses perencanaan, pengorganisasian, pelaksanaan, dan pengawasan dalam rangka mencapai tujuan bersama.

\section{Manajemen Bencana}

Menurut Carter (1991) yang dikutip oleh Nisa (2014), manajemen bencana merupakan an apllied system, with seeks, by the systematic observation and analysis of disaster and inprove measures relating to prevention, mitigation, preparedness, emergency response and recovery. 
Penyelenggaraan manajemen bencana dilakukan melalui tahapan-tahapan: persiapan (preparation), penghadangan/penanganan (facing disaster), perbaikan akibat kerusakan (recontruction), pemfungsian kembali prasarana dan sarana sosial yang rusak (rehabilitation), dan penjinakkan gerak alam yang menimbulkan bencana (mitigation). Namun demikian dalam pelaksanaannya tahapan-tahapan tersebut tidak mutlak, karena bisa yang satu mendahului yang lain (Prayogo, 2008). Hal ini merupakan proses penting dalam menyikapi untuk pengambilan tindakan dan penyelesaian pasca bencana. Oleh karena itu proses yang dilakukan secara lintas sektoral dan terintegrasi serta berkelanjutan dalam rangka mencegah dan mengurangi akibat bencana, meliputi mitigasi, kewaspadaan, tanggapan terhadap bencana alam serta upaya pemulihan (Warto dkk, 2003).

Menurut Alexander (2014) siklus manajemen bencana terdapat empat aktivitas yang sangat penting dilakukan yaitu mitigasi, kesiapsiagaan, respon dan rekonstruksi. Mitigasi didefinisikan sebagai tindakan yang diambil sebelum bencana terjadi dengan tujuan untuk mengurangi atau menghilangkan dampak bencana terhadap masyarakat dan lingkungan. Sementara itu, kesiapsiagaan berarti perencanaan tindakan untuk merespon jika terjadi bencana, dan dapat didefinisikan sebagai suatu keadaan siap siaga dalam menghadapi krisis, bencana atau keadaan darurat lainnya. Adapun yang dimaksud dengan respon/ daya tanggap yaitu upaya yang dilakukan segera sebelum, selama, dan setelah bencana terjadi, di mana tujuan dari kegiatan ini adalah untuk menyelamatkan nyawa, mengurangi kerusakan harta benda, dan meningkatkan pemulihan awal dari insiden tersebut. Kemudian yang terakhir adalah pemulihan (recovery), dimana kegiatan mengembalikan sistem infrastruktur kepada standar operasi minimal dan panduan upaya jangka panjang yang dirancang untuk mengembalikan kehidupan pada keadaan dan kondisi normal atau keadaan yang lebih baik setelah bencana. Dalam teori manajemen bencana yang dikemukan oleh Nick Carter (1991), manajemen bencana terdiri dari enam tahapan yaitu prevention (pencegahan), mitigation (peringatan), preparedness (kesiapsiagaan), disaster impact (dampak bencana), response (tanggapan), recovery (pemulihan), dan development (pembangunan).

\section{Manajemen Kolaboratif Penanggulangan Bencana}

Purnomo dan Sugiantoro (2010) mengemukakan tentang tahapan-tahapan atau fase-fase dalam penanggulangan bencana dalam suatu siklus yang dikenal dengan siklus penanganan bencana (disaster management cycle), yang menggambarkan tentang proses pengelolaan bencana di mana pada intinya merupakan tindakan pra bencana, menjelang bencana, saat bencana dan pasca bencana. Manajemen kolaboratif dalam penanggulangan bencana didasarkan pada teori jejaring (networking theory). Dalam istilah yang lebih luas, networking atau jejaring didefinisikan sebagai hubungan timbal balik yang abadi antar organisasi, individu 
dan kelompok (Kusumasari, 2014). Hall dan O’Toole (2004) dalam artikelnya menjelaskan bahwa hubungan dalam jejaring merupakan pengaturan antar organisasi yang sederhana atau kombinasi organisasi, kelompok dan individu dari berbagai sektor yang kompleks. Analisis jaringan berfokus pada struktur hubungan tersebut dengan implikasi terhadap perilaku dan kinerja serta pada cara-cara mengukur kapasitas kolaboratif (Kusumasari, 2014). Manajemen kolaboratif pada penanggulangan bencana dipelopori oleh organisasi PBB yaitu International Organization such as the UN High commissioner for Refugees (UNHCR) dan the World Food Program (WFP) yang beroperasi dibawah mandat 192 negara anggota. Manajemen kolaboratif dalam penanganan bencana yang memerlukan bantuan dari luar, maka negara yang terkena bencana harus berupaya berkoordinasi, memanage dan menerima tim dari negara-negara tetangga atau dari daerah yang sama untuk memberi pertolongan pada 24 jam pertama sebelum ada pendampingan dari tim internasional (PBB) (Sujarwoto, 2018).

Dalam kolaborasi, Gorp dan Van (2014) mengemukakan bahwa data sangat mendukung organisasi bantuan kemanusiaan yaitu adanya keterbukaan dalam menggunakan data oleh sukarelawan dan komunitas teknisi. Kepercayaan dan komitmen dapat meningkatkan tingkat penyebaran informasi. Inilah yang menjadi masalah dalam manajemen sukarelawan yaitu tidak terkelolanya data dengan baik, dan masalah lainnya adalah keahlian para sukarelawan. Para sukarelawan tidak memiliki latar belakang keahlian dalam bantuan kemanusiaan dan dari bidang keahlian yang berbeda-beda. Ditambah, mereka berhadapan dengan cara kerja yang berbeda, kesetaraan atau pembagian kerja yang terstruktur. Oleh karena itu Bealt (2018) berpendapat bahwa dalam manajemen kolaborasi bencana, hal yang harus disoroti adalah keahlian komunitas bantuan kemanusiaan dan penggunaan sumber daya jejaring bantuan kolaborasi dan komunitas kemanusiaan. Pada dasarnya bantuan kemanusiaan dengan manajemen kolaboratif dapat bekerja dengan cepat, efisien dan efektif membantu dalam berbagai tahapan bencana.

\section{Faktor-Faktor Pendukung dan Penghambat Manajemen Kolaboratif Penanggulangan Bencana}

Keberhasilan dari suatu sistem manajemen dipengaruhi oleh banyak faktor, baik faktor pendukung maupun faktor penghambat. Terkait dengan faktor pendukung dan faktor penghambat dalam konteks manajemen kolaborasi ini, dalam penelitian ini menggunakan teori yang dikemukakan oleh Ansell dan Gash (2007) sebagai teori utama. Ansell dan Gash (2007) mengemukakan bahwa faktor yang dapat mendukung manajemen kolaborasi antara lain adalah komunikasi yang dilakukan dua arah dan yang membangun kepercayaan antar stakeholder, komitmen para stakeholder selama proses kolaborasi, dan saling memahami di antara para stakeholder. Faktor yang dapat menghambat manajemen kolaborasi di lapangan, adalah ketidakseimbangan sumber daya atau kekuatan karena perbedaan pada stakeholder, imbalan 
yang diterima bila stakeholder berkolaborasi, dan sejarah konflik atau kerjasama di masa lalu di antara stakeholder.

\section{METODE PENELITIAN}

Jenis penelitian iniadalahpenelitian kualitatif yaitu deskripsif kualitatif dengan menggunakan metode studi kasus. Lokasi penelitian dilaksanakan di Kabupaten Banjarnegara, antara lain di kantor Badan Penanggulangan Bencana Daerah, kantor Pemerintah Daerah kabupaten Banjarnegara, kantor DPRD kabupaten Banjarnegara. Sasaran dalam penelitian ini yaitu Kepala BPBD dan Kepala Bagian Pelaksana BPBD, Bupati Banjarnegara, DPRD kabupaten Banjarnegara Komisi D, dan Kepala Kantor Dinas Sosial sebagai sasaran utama, sedangkan ketua oganisasi masyarakat dan masyarakat sebagai sasaran pendukung. Teknik pengambilan informan menggunakan teknik purposive sampling. Informan dalam penelitian ini terdiri dari informan utama dan informan pendukung. Informan utama adalah Kepala BPBD dan Kepala Bagian Pelaksana BPBD, Dinas Kesehatan, Bupati Banjarnegara, DPRD Kabupaten Banjarnegara Komisi D, dan Kepala Kantor Dinas Sosial. Informan pendukung adalah ketua oganisasi masyarakat atau organisasi kepemudaan yang pernah ikut menangani bencana, dan masyarakat terdampak bencana apabila dibutuhkan.

\section{HASIL DAN PEMBAHASAN}

\section{Bencana di Kabupaten Banjarnegara dan Penanganannya}

Kabupaten Banjarnegara termasuk salah satu daerah di Indonesia yang sering terjadi bencana terutama tanah longsor. Jenis bencana alam di Kabupaten Banjarnegara yang rawan terjadi yaitu longsor, gas beracun, kekeringan, dan banjir. Hampir 70 persen wilayah banjarnegara atau 199 desa dari 20 Kecamatan yang rawan longsor merupakan area perbukitan dan gunung gunung menyebabkan seringnya terjadi longsor. Selama tahun 6 tahun terakhir telah terjadi 1.006 bencana yang terdiri dari bencana Tanah longsor, Banjir, Angin Kencang, Gempa, Kebakaran dan Erupsi. Salah satu kejadian terbesar di Banjarnegara yaitu tanah longsor terbesar terjadi di akhir tahun 2014 yang menyebabkan satu di Dusun Jemblung, Desa Sampang Kecamatan Karangkobar tertimbun dan 125 orang penduduk meninggal dunia. Selain tanah longsor Kabupaten Banjarnegara juga pernah mengalami bencana gempabumi yang mengakibatkan kerusakan parah. Pada tahun 2018, gempa bumi berkekuatan 4,4 skala richter dengan kedalaman $4 \mathrm{~km}$ di bawah permukaan tanah di Kecamatan Kalibening mengakibatkan kerusakan yang cukup besar di 5 (lima) Desa yaitu Kertosari, Kasinoman, Plorengan, Sidakangan dan Kalibening dengan sedikitnya 767 rumah mengalami kerusakan ringan hingga berat. Banyaknya bencana yang terjadi di wilayah Kabupaten Banjarnegara dan adanya kendala atau permasalahan yang ditemukan saat proses penanganan bencana di lapangan menyebabkan banyak yang penanganan paasca bencana yang belum selesai ditangani. Kejadian bencana yang 
sampai saat ini belum selesai tertangani terkait pasca bencana sejak tahun 2014 hingga 2019, sebagai berikut :

Tabel 2. Bencana yang belum selesai ditangani tahun 2014-2019

\begin{tabular}{|c|c|c|c|c|c|c|c|}
\hline No & JENIS KEJADIAN & $\begin{array}{l}\text { TAHUN } \\
\text { KEJADIAN }\end{array}$ & DESA & KECAMATAN & $\begin{array}{l}\text { JUMLAH } \\
\text { KK }\end{array}$ & $\begin{array}{c}\text { JENIS } \\
\text { PENANGANAN }\end{array}$ & PROSES PENANGANAN \\
\hline 1 & TANAH LONGSOR & 2014 & KARANGTENGAH & WANAYASA & 38 & RELOKASI & $\begin{array}{l}\text { STATUS TANAH BELUM } \\
\text { SELESAI }\end{array}$ \\
\hline 2 & TANAH LONGSOR & 2014 & PANDANSARI & WANAYASA & 25 & RELOKASI & $\begin{array}{l}\text { STATUS TANAH BELUM } \\
\text { SELESAI }\end{array}$ \\
\hline 3 & TANAH LONGSOR & 2014 & DUREN & PAGEDONGAN & 21 & RELOKASI & $\begin{array}{l}\text { STATUS TANAH BELUM } \\
\text { SELESAI }\end{array}$ \\
\hline 4 & TANAH LONGSOR & 2013 & ARIBAYA & PAGENTAN & 40 & RELOKASI & PENYEDIAAN LAHAN \\
\hline 5 & TANAH LONGSOR & 2016 & SUWDAK & WANAYASA & 44 & RELOKASI & $\begin{array}{l}\text { SUDAH PEMERATAAN } \\
\text { TANAH }\end{array}$ \\
\hline 6 & TANAH LONGSOR & 2016 & CLAPAR & MADUKARA & 21 & RELOKASI & $\begin{array}{l}\text { DALAM PROSES } \\
\text { PEMBANGUNAN } \\
\end{array}$ \\
\hline 7 & TANAH LONGSOR & 2014 & SUERUK & BANJARMANGU & 13 & RELOKASI & SUDAH DIBANGUN \\
\hline 8 & TANAH LONGSOR & 2016 & MLAYA & PUNGGELAN & 27 & RELOKASI & BELUM DIBANGUN \\
\hline 9 & $\begin{array}{l}\text { PERGERAKAN } \\
\text { TANAH } \\
\end{array}$ & 2015 & KALIAJIR & PURWANEGARA & 60 & RELOKASI & BELUM DIBANGUN \\
\hline 10 & $\begin{array}{l}\text { PERGERAKAN } \\
\text { TANAH }\end{array}$ & 2015 & GUMINGSIR & PAGENTAN & 85 & $\begin{array}{l}\text { RELOKASI } \\
\text { MANDIRI }\end{array}$ & $\begin{array}{l}\text { SEBAGIAN SUDAH } \\
\text { DIBANGUN }\end{array}$ \\
\hline 11 & TANAH LONGSOR & 2108 & BANTAR & WANAYASA & 51 & RELOKASI & $\begin{array}{l}\text { DALAM PROSES } \\
\text { PEMBANGUNAN }\end{array}$ \\
\hline 12 & GEMPA BUMI & 2018 & KASINOMAN & KALIBENING & 125 & REKONTSRUKSI & $\begin{array}{l}\text { DALAM PROSES } \\
\text { PEMBANGUNAN }\end{array}$ \\
\hline 13 & GEMPA BUMI & 2018 & KERTOSARI & KALIBENING & 88 & REKONTSRUKSI & $\begin{array}{l}\text { DALAM PROSES } \\
\text { PEMBANGUNAN }\end{array}$ \\
\hline 14 & GEMPA BUMI & 2018 & PLORENGAN & KALIBENING & 7 & REKONTSRUKSI & $\begin{array}{l}\text { DALAM PROSES } \\
\text { PEMBANGUNAN }\end{array}$ \\
\hline 15 & GEMPA BUMI & 2018 & SIDAKANGEN & KALIBENING & 18 & REKONTSRUKSI & $\begin{array}{l}\text { DALAM PROSES } \\
\text { PEMBANGUNAN }\end{array}$ \\
\hline 16 & TANAH LONGSOR & 2019 & $\begin{array}{l}\text { KEBUTUH } \\
\text { JURANG }\end{array}$ & PAGEDONGAN & 23 & RELOKASI & BELUM DIBANGUN \\
\hline \multicolumn{5}{|c|}{ JUMLAH } & 374 & & \\
\hline
\end{tabular}

Sumber: BPBD kabupaten Banjarnegara, 2019

Dari data diatas diketahui bahwa ada permasalahan dalam penanganan bencana di kabupaten Banjarnegara, dan perlu dilakukan upaya sinergi atau kolaborasi sehingga penanganan pasca bancana dapat tertangani dengan baik dengan anggaran yang memadai dengan kondisi lapangan terkena dampak bencana.

\section{Manajemen Kolaboratif Penanggulangan Bencana di Kabupaten Banjarnegara (tahap ressponse, recovery dan developing)}

Tahap response; tahap response sudah berjalan dengan cukup baik dan banyak pihak yang bekerja sama melakukan tanggap darurat. Pada tahap ini melakukan kegiatan: evakuasi korban, pembersihan wilayah terdampak, membuat posko pengungsian sementara beserta pelayanan kesehatan, membuat dapur umum, pendataan korban dan kebutuhan korban, mengelola bantuan dan mendistribusikan kepada para korban. Tahap recovery; tahap recovery sudah dilakukan dengan cukup baik ada masalah keterbatasan anggaran. Pada tahap ini bekerja sama dengan dinas sosial, dinas kesehatan, dinas pendidikan. Korban diberi bantuan berupa uang dan barang, bantuan psikologis terutama bagi anak-anak agar tidak mengalami trauma, dan pelatihan ketrampilan beserta peralatannya. Tahap developing; BPBD bekerja sama dengan dinas lain seperti Dinas Pekerjaan Umum, Dinas Perumahan, PLN dan PDAM. Tahap developing merupakan proses yang membutuhkan waktu cukup panjang dan melalui beberapa proses 
serta berhubungan langsung dengan beberapa pihak yang kadang kurang mendukung percepatan proses developing.

Secara keseluruhan manajemen kolaboratif di Kabupaten Banjarnegara pada tahap response, recovery, dan developing sudah dapat terlaksana dengan cukup baik, yang ditandai dengan: dampak bencana dapat ditanggulangi dengan cukup efisien dan efektif; pelayanan publik dalam penanganan bencana dapat dianggap maksimal karena sampai pada tahap pembangunan termasuk pembangunan rumah pribadi penduduk yang mengalami rusak ringa, sedang dan berat; masyarakat terdampak bencana dapat melanjutkan aktivitas kehidupannya dengan normal kembali. Hal ini tidak lepas dari peran pemerintah dalam manajemen kolaboratif penanggulangan bencana di Kabupaten Banjarnegara yang sudah mencukupi, yaitu sebagai leading sector. Pemerintah juga berkomitmen dengan semua elemen mulai dari segi kebijakan, sumber daya manusia, anggaran maupun rencana penanggulangan bencana sesuai dengan ancaman bencana yang ada di Kabupaten Banjarnegara.

\section{Peran Pemerintah pada Manajemen Kolaborasi Penanggulangan Bencana di Kabupaten Banjarnegara}

Penanggulangan bencana di suatu daerah tidak bisa lepas dari peran pemerintah selaku penanggungjawab wilayah yang tentunya bertanggung jawab atas semua hal yang terjadi di wilayah kerjanya, termasuk bencana yang menimpa di salah satu wilayah lingkup tanggung jawabnya. Demikian pula penanggulangan bencana di Kabupaten Banjarnegara, tidak bisa lepas dari peran pemerintah. Peran pemerintah dalam manajemen kolaborasi penanggulangan bencana di Kabupaten Banjarnegara dapat diperoleh gambarannya melalui hasil penelitian yang diperoleh dari wawancara. Sekda Kabupaten Banjarnegara (wawancara pada tanggal 27 Desember 2019 pukul 10.15 - 13.00 WIB) menerangkan bahwa sejauh ini pemerintah sudah berupaya dan berkomitmen dalam menajemen kolaborasi dengan semua elemen mulai dari kebijakan, sumber daya manusia, anggaran maupun rencana penanggulangan bencana sesuai dengan ancaman bencana yang ada di Banjarnegara. Kepala Dinkes Kabupaten Banjarnegara (wawancara pada tanggal 26 Desember 2019 pukul 10.00 - 13.00 WIB) menerangkan bahwa peran pemerintah adalah sebagai liding sektor dalam mengorganilisir penanggulangan bencana, memanejemen bantuan dan pendistribusiannya, dan penanganan pasca bencana. Kepala Bagian Pelaksana BPBD (wawancara pada tanggal 17 Desember 2019 pukul 09.30 - 13.00 WIB) berpendapat bahwa peran pemerintah sudah baik karena Bupati dan Forkompinda merespon pada saat kejadian bencana, Kepala Dinsos (wawancara pada tanggal 18 Desember 2019 pukul 09.45 - 12.00 WIB) juga memiliki pendapat yang sama yaitu bahwa peran pemerintah sudah baik dari sisi aturannya, kemudian sebagai koordinatornya, dan adanya Permendagri sebagai payung hukum tentang kewenangan daerah dalam bencana alam. Demikian pula menurut DPRD Komisi D (wawancara pada tanggal 30 Desember 2019 pukul 10.30 - 12.00 WIB) merasa peran 
pemerintah sudah mencukupi dengan adanya bansos atau bantuan sosial kepada korban bencana.

Hasil penelitian tentang harapan manajemen kolaboratif penanggulangan bencana di Kabupaten Banjarnegara di masa-masa mendatang adalah seperti berikut: Sekda Kabupaten Banjarnegara (wawancara pada tanggal 27 Desember 2019 pukul 10.15 - 13.00 WIB) berharap dalam penanggulangan bencana semua memiliki regulasi, kemampuan, kapasitas, anggaran, SDM dan peralatan penunjang penanggulangan bencana untuk mewujudkan tujuan yaitu Pengurangan Risiko Bencana. Kepala Dinkes Kabupaten Banjarnegara (wawancara pada tanggal 26 Desember 2019 pukul 10.00 - 13.00 WIB) mengharapkan adanya dukungan konkrit atau lebih dari pemerintah kabupaten terutama berupa peralatan-peralatan yang mendukung penanggulanngan bencana. Kepala Bagian Pelaksana BPBD (wawancara pada tanggal 17 Desember 2019 pukul 09.30 - 13.00 WIB) mengakui bahwa BPBD masih kurang SDM dan sarana prasarana, karena itu pada tahun 2020 berharap lebih baik lagi yaitu mengalami peningkatan dari tipe A menjadi 2B artinya dibantu oleh para kasubag dengan kepala bidang, saat ini hanya dibantu oleh kasi saja, dan adanya penambahan personil serta anggaran pada saat kejadian bencana dari pemerintah. Kepala Dinsos (wawancara pada tanggal 18 Desember 2019 pukul 09.45 - 12.00 WIB) berharap kedepannya dalam penanggulangan bencana terjadi sinergritas dan keterpaduan antar lembaga dalam penanganan bencana.Semetara Kepala BPBD Kab. Banjarnegara (wawancara pada tanggal 27 Desember 2019 pukul 10.15 - 13.00 WIB) berharap: 1) ada perubahan mindset tentang faktor alam dengan pencegahan yang dilakukan oleh masyarakat bila kita menjaga alam maka alam juga akan menjaga kita, bencana merupakan takdir bahwa kita harus ikhtiar, 2) media masa mendorong masyarakat agar menjaga alam, 3) Mitigasi secara struktural dan non struktural (penguatan kapasitas pribadi), 4) ada peta resiko dan renkon (rencana konferengensi). Harapan dari DPRD Komisi D (wawancara pada tanggal 30 Desember 2019 pukul 10.30 - 12.00 WIB) adalah terpenuhinya anggaran yang cukup, fasilitas sarana dan prasarana yang memadai. Dari masyarakat yang diwakili oleh Ibu Surtanti selaku tokoh masyarakat (wawancara pada tanggal 21 Desember 2019 pukul 10.15 - 13.00 WIB) berharap masyarakat secara mandiri memiliki edukasi yang cerdas untuk menolong diri sendiri, ada keterkaitan dan tepat sasaran terhadap sistem penanggulangan bencana, sumber dana untuk penanggulangan bencana alam maksimal khususnya dari dunia usaha, dan adanya keterpaduan lintas sektor dalam tanggap bencana dari unsur poerholder dan stekholder.Bapak Cahyono selaku tokoh masyarakat (wawancara pada tanggal 28 Desember 2019 pukul 10.00 13.00 WIB) berharap dapat mendeteksi lebih dini untuk mengetahui bencana yang akan terjadi di Kabupaten Banjarnegara dan masyarakat menjaga lingkungan di sekitar.

Menurut peneliti, secara komprehensif manajemen kolaboratif penanggulangan bencana di Kabupaten Banjarnegara belum efektif dan belum efisien, karena masih ada 
tahapan penanganan bencana di Kabupaten Banjarnegara yang belum selesai tepat waktu, walaupun sudah ada bantuan dari pihak luar seperti dari pemerintah pusat atau provinsi dan lembaga non pemerintah. Belum efektifnya manajemen kolaboratif penanggulangan bencana di Kabupaten Banjarnegara dibuktikan dengan masih adanya penanganan bencana pada tahap recovery dan developing yang belum selesai hingga saat ini, seperti yang tercantum pada Tabel 2 yaitu tabel bencana yang penanganannya belum selesai tahun 2014-2019 seperti yang sudah diuraikan di atas. Dengan demikian maka dapat dikatakan bahwa secara keseluruhan manajemen kolaboratif di Kabupaten Banjarnegara pada tahap response, recovery, dan developing sudah dapat terlaksana dengan cukup baik namun belum sepenuhnya efektif dan efisien..

\section{Faktor Pendukung Manajemen Kolaboratif Penanggulangan Bencana di Kab. Banjarnegara}

Berdasarkan hasil penelitian, maka secara komprehensif dapat dikatakan bahwa faktor pendukung manajemen kolaboratif penanggulangan bencana di Kabupaten Banjarnegara yang paling utama adalah adanya kerjasama dan kesadaran dari semua lembaga pemerintah yang terkait dan dari lembaga non pemerintah serta unsur masyarakat yang sadar akan tugas dan tanggungjawab masing-masing dan perlunya kolaborasi dalam upaya penanggulangan bencana. Serta kesadaran semua pihak bahwa potensi bencana di Banjarnegara cukup tinggi dan memerlukan langkah-langkah bersama dalam melayani masyarakat. Dengan demikian dapat dikatakan bahwa faktor pendukung manajemen kolaborasi penanggulangan bencana di Kabupaten Banjarnegara adalah komunikasi dua arah antar stakeholder yang dapat membangun kepercayaan dan koordinasi yang baik di antara mereka, adanya komitmen dari para stakeholder dalam melaksanakan tugas dan tanggungjawabnya masing-masing, saling memahami satu dengan yang lain, sehingga kolaborasi yang dijalankan dapat memberi solusi yang tepat bagi permasalahan yang dihadapi dalam penanggulangan bencana. Faktor pendukung dalam manajemen kolaborasi penanggulangan bencana di Kabupaten Banjarnegara ini sejalan dengan teori yang dikemukakan oleh Ansell dan Gash (2007) yaitu bahwa faktor yang dapat mendukung pelaksanaan manajemen kolaborasi adalah adanya komunikasi dua arah yang mampu membangun kepercayaan antar stakeholder, komitmen para stakeholder selama proses kolaborasi, dan saling memahami di antara para stakeholder.

\section{Faktor Penghambat Manajemen Kolaboratif Penanggulangan Bencana di Kab. Banjarnegara}

Berdasarkan keterangan dari para informan yang diwawancai pada penelitian ini, diketahui bahwa banyak faktor penghambat pelaksanaan manajemen kolaborasi penanggulangan bencana di Kabupaten Banjarnegara, antara lain adalah sebagai berikut: 1) 
kondisi geografis karena di Kabupaten Banjarnegara yaitu pegunungan yang sangat rawan terhadap bencana, 2) anggaran / dana yang masih kurang, 3) budaya (mindset masyarakat) 3) ketidakseimbangan sumberdaya pada para stakeholder, diantaranya adalah SDM yang sangat terbatas secara kuantitas dan kualitas, 4) peralatan terutama alat berat untuk melakukan evakuasi atau pembersihan lokasi bencana.

Faktor penghambat pada manajemen kolaboratif penanggulan bencana di Kabupaten Banjarnegara seperti yang sudah disebutkan di atas, yang paling mendasar adalah karena adanya ketidakseimbangan sumberdaya stakeholder karena adanya keterbatasan SDM, peralatan dan keterbatasan anggaran. Menurut peneliti, faktor penghambat berupa ketidakseimbangan sumberdaya stakeholder yang ditunjukkan adanya keterbatasan SDM, peralatan dan keterbatasan anggaran sejauh ini masih dapat dicover dengan adanya faktor pendukung yang utama yaitu komunikasi, komitmen dan saling memahami di antara stakeholder yang terwujud dalam kerjasama dan kesadaran dari para stakeholder di Kabupaten Banjarnegara dalam menanggulangi bencana yang terjadi di wilayah Kabupaten Banjarnegara sejak proses ketanggapan hingga pembangunan. Sumber daya yang paling banyak dibutuhkan dari kolaborasi bukan uang tapi waktu dan energi, begitu juga dapat menjadi penyebabnya. Oleh karena itu komunikasi, komitmen dan saling memahami di antara stakeholder yang terwujud dalam kesadaran akan adanya kerjasama dari semua stakeholder akan sangat mendukung berjalannya kolaborasi. Dengan demikian maka dapat ditegaskan bahwa faktor penghambat manajemen kolaborasi penanggulangan bencana di Kabupaten Banjarnegara bukanlah konflik diantara stakeholder, ketidakseimbangan sumberdaya atau kemampuan yang dimiliki oleh para stakeholder yang terlibat dalam kolaborasi, atau adanya konflik di masa lalu seperti teori yang dikemukakan oleh Ansell dan Gash (2007) yaitu bahwa ketidakseimbangan sumber daya atau kekuatan karena perbedaan pada stakeholder, imbalan yang diterima bila stakeholder tersebut harus berkolaborasi, dan sejarah konflik atau kerjasama di masa lalu di antara stakeholder.

Ansell dan Gash (2007) lebih lanjut menerangkan bahwa ketidakseimbangan kekuatan antara stakeholder menimbulkan masalah dalam collaborative governance apabila beberapa stakeholder tidak mempunyai kapasitas, status, sumber daya - sumber daya untuk berpartisipasi atau bekerja sama dengan stkaholder lainnya, maka proses collaborative governance akan dimanipulasi oleh aktor terkuat. Kemudian apabila stakeholder tidak mendapat insentif/imbalan apa-apa dengan keterlibatannya dalam kolaborasi, maka tidak termotivasi untuk lebih partisipatif dalam kolaborasi. Konflik yang pernah terjadi di masa lalu dapat menciptakan kecurigaan, ketidakpercayaan dan stereotipe di sisi lain sejarah kerja sama yang sukses di masa lalu dapat menciptakan modal sosial dan tingginya tingkat kepercayaan yang menghasilkan siklus kolaborasi yang santun. 
Fakta yang ditemukan dari hasil penelitian manajemen kolaborasi penanggulangan bencana di Kabupaten Banjarnegara adalah ketidakseimbangan kekuatan antara stakeholder tidak menjadi masalah dan tidak dimanipulasi oleh aktor terkuat, sebaliknya yang terjadi dengan adanya ketidakseimbangan tersebut adalah saling melengkapi dan saling membantu di mana yang stakeholder dengan sumberdaya kuat akan membantu stakeholder yang sumberdayanya kurang. Stakeholder dengan sumberdaya kuat dan kurang semua berpartisipasi sesuai dengan kapasitas dan kemampuan mereka untuk mengatasi bencana. Hasil penelitian dari informan mengungkapkan bahwa keterbatasan anggaran, keterbatasan SDM baik secara kuantitas maupun kualitas menjadi faktor penghambat manajemen kolaborasi dalam penanggulangan bencana di Kabupaten Banjarnegara. Kondisi ini sejalan dengan hasil penelitian Pubita Sasti Fintani (2013) yaitu selain pelaksanaan koordinasi tim yang belum baik, keberadaan sumber daya finansial penanggulangan bencana yang belum sesuai dengan kemampuan APBD (keterbatasan dana) sehingga dibutuhkan dana bantuan dari Pemerintah Pusat maupun Pemerintah Provinsi untuk menanggulangi bencana yang terjadi di wilayah Kabupaten Pemalang.

\section{Strategi yang dilakukan untuk mengatasi hambatan yang ada}

Adanya faktor penghambat dari manajemen kolaboratif penanggulangan bencana di Kabupaten Banjarnegara, disadari betul oleh pihak pemerintah khususnya BPBD selaku koordinator pelaksana manajemen kolaboratif penanggulangan bencana di Kabupaten Banjarnegara. Oleh karena itu selama ini sudah dilakukan upaya-upaya guna mengatasi hambatan tersebut. Upaya yang dilakukan untuk mengatasi hambatan dalam pelaksana manajemen kolaboratif penanggulangan bencana di Kabupaten Banjarnegara adalah seperti yang diterangkan oleh para informan penelitian berikut ini.

Menurut Sekda Kabupaten Banjarnegara (wawancara pada tanggal 27 Desember 2019 pukul 10.15 - 13.00 WIB) adalah melakukan evaluasi dan melakukan koordinasi semua elemen dan dibutuhkan komitmen bersama dalam Penanggulangan Bencana.Kepala Dinkes Kabupaten Banjarnegara (wawancara pada tanggal 26 Desember 2019 pukul 10.00 - 13.00 WIB)menyebutkan upayanya adalah melakukan sosialisasi dan pengadaan alat - alat bantu (alat deteksi dini). Kepala Bagian Pelaksana BPBD (wawancara pada tanggal 17 Desember 2019 pukul 09.30 - 13.00 WIB) menerangkan upaya yang dilakukan adalah mengusulkan untuk melakukan stok opname, anggaran bencana dan penambahan personil. Kepala Dinsos (wawancara pada tanggal 18 Desember 2019 pukul 09.45 - 12.00 WIB) menyebutkan upayaupaya yang dilakukan adalah reboisasi (penghijauan), penyuluhan kepada masyarakat untuk melakukan pola tanam yang benar, dan penyuluhan kepada masyarakat untuk membangun rumah sesuai rencana tata ruang. Sementara Kepala BPBD Kabupaten Banjarnegara (wawancara pada tanggal 27 Desember 2019 pukul 10.15 - 13.00 WIB) mengungkapkan upaya 
yang dilakukan antara lain adalah membangun komunikasi intens untuk meningkatkan ikatan emosional, membangun rasa empati, dan tidak lupa memberi ucapan terima kasih atas dukungan yang telah diberikan. Sedangkan DPRD Komisi D (wawancara pada tanggal 30 Desember 2019 pukul 10.30 - 12.00 WIB) mengupayakan dengan menghimbau kepada masyarakat untuk waspada terjadinya bencana, tidak membangun rumah di daerah rawan bencana dan tidak menebang pohon sembarangan.

Berdasarkan keterangan yang dikemukakan oleh para informan di atas, diketahui bahwa upaya yang dilakukan untuk mengatasi hambatan yang ada dalam manajemen kolaboratif dalam penanggulangan bencana di Kabupaten Banjarnegara dilakukan secara internal dan eksternal. Upaya internal dilakukan dengan cara melakukan evaluasi, melakukan stok opname, penambahan anggaran bencana, penambahan personil dan pengadaan alat - alat bantu (alat deteksi dini). Upaya eksternal dengan melakukan reboisasi (penghijauan), sosialisasi dan penyuluhan kepada masyarakat untuk melakukan pola tanam yang benardan membangun rumah sesuai rencana tata ruang, melakukan koordinasi dengan semua elemen, menumbuhkan komitmen untuk bekerja sama dalam penanggulangan bencana, membangun komunikasi yang lebih intensif untuk meningkatkan ikatan emosional, membangun rasa empati dan memberi ucapan terima kasih atas dukungan yang telah diberikan kepada semua elemen utamanya elemen di luar lembaga pemerintahan.

Menurut Ansell dan Gash (2007), komunikasi yang dilakukan dua arah dan yang membangun kepercayaan antar stakeholder, komitmen para stakeholder selama proses kolaborasi dan saling memahami di antara para stakeholder dapat mendukung pelaksanaan manajemen kolaborasi penanggulangan bencana. Sehingga upaya dalam bentuk koordinasi dengan semua elemen, menumbuhkan komitmen untuk bekerja sama, membangun komunikasi yang lebih intensif untuk meningkatkan ikatan emosional, membangun rasa empati dan memberi ucapan terima kasih adalah upaya yang tepat dalam mengatasi keterbatasanketerbatasan pada menajemen kolaboratif penanggulangan bencana di Kabupaten Banjarnegara saat ini.

Upaya lain adalah seperti yang dikemukakan oleh Noran (2014) dalam penelitianya yaitu penanganan bencana yang dibangun dari interdisiplin, paradigma industri-based yang ada dan jejaring kolaborasi dan disiplin ilmu arsitektur dan jejaring kolaborasi dan disiplin ilmu arsitektur merupakan pendekatan kombinasi yang diajukan sebagai platform untuk mengefisienkan tanggap darurat bencana yang cerdas dan sinergisme petugas penanganan bencana di baris depan. Menurut peneliti keterbatasan anggaran dan jumlah SDM sudah dapat diatasi dengan adanya stakeholder lain dengan kapasitas lebih dari sisi SDM, anggaran dan peralatan yang ikut berpartisipasi dalam kolaborasi penanggulangan bencana di Kabupaten Banjarnegara. Sehingga keterbatasan proses penanggulangan bencana dapat berjalan kembali. 
Kondisi ini sejalan dengan penelitian Sonia Regina Hierro Parolin1, Eduardo Vasconcellos, Maricilia Volpato, dan Alisson Marcelo Laurindo (2013) yang menyimpulkan bahwa upaya manajemen kolaborasi dalam menanggulangi hambatan budaya, hukum dan ekonomi yang terkonsentrasi pada mekanisme pemerintah mampu menimbulkan kerjasama antara perusahaan dengan universitas dalam membangun proyek R\&D.

\section{KESIMPULAN}

Berdasarkan hasil penelitian dan pembahasan tentang manajemen kolaboratif penanggulangan bencana di Kabupaten Banjarnegara yang sudah dijelaskan pada bab sebelumnya, maka diperoleh kesimpulan sebagai berikut:

1. Manajemen kolaboratif di Kabupaten Banjarnegara secara keseluruhan belum sepenuhnya berjalan secara efektif dan efisien namun dapat dikatakan cukup baik yang ditandai dengan: a) Dampak bencana sudah tertanggulangi pada tahap response dan recovery cukup efisien dan efektif, sedang pada tahap developing belum efisien dan efektif,, b) Penanganan bencana yang dilakukan dapat dianggap maksimal, dan c) Masyarakat terdampak bencana dapat melanjutkan aktivitas kehidupannya dengan normal kembali. Walaupun pelaksanaannya belum sepenuhnya efektif dan efisien seperti yang diharapkan dan belum sepenuhnya dapat memuaskan masyarakat secara keseluruhan. Pada tahap response sudah berjalan cukup baik, pada tahap recovery berjalan cukup baik, dan tahap developing juga berjalan cukup baik namun banyak yang belum selesai dibangun karena terkendala pembebasan tanah warga. BPBD dapat berkolaborasi dengan berbagai unsur lembaga pemerintah dan lembaga non pemerintah, ormas dan masyarakat dalam rangka mencapai tujuan bersama yaitu meminimalisir jumlah korban dan resiko dampak bencana.

2. Faktor pendukung manajemen kolaboratif penanggulangan bencana di Kabupaten Banjarnegara adalah adanya komunikasi, komitmen dan saling memahami diantara para stakeholder yang direalisasikan dengan kerjasama dan kesadaran dari semua elemen yang sadar akan tugas dan tanggungjawab masing-masing dalam upaya penanggulangan bencana. Sehingga faktor penghambat berupa keterbatasan SDM, peralatan dan anggaran dapat teratasi dengan adanya kolaborasi tersebut. Peran dan komitmen pemerintah Kabupaten Banjarnegara sebagai leading sector sejauh ini sudah baik dan sangat mendukung manajemen kolaboratif penanggulangan bencana di Kabupaten Banjarnegara, di mana pemerintah berkomitmen melalui kebijakan, sumber daya manusia, anggaran maupun rencana penanggulangan bencana sesuai ancaman bencana di masing-masing wilayah di Kabupaten Banjarnegara.

\section{Keterbatasan Penelitian}

Penelitian tentang manajemen kolaboratif penanggulangan bencana di Kabupaten Banjarnegara ini, hanya memfokuskan kajian penelitian pada deskripsi manajemen kolaboratif 
penanggulangan bencana di Kabupaten Banjarnegara yang sudah dilakukan di Kabupaten Banjarnegara selama ini, dan deskripsi penanggulangan bencana pada tahap response, recovery, dan developing saja, sedangkan manajemen bencana terdiri dari enam tahapan yaitu prevention (pencegahan), mitigation (peringatan), preparedness (kesiapsiagaan), disaster impact (dampak bencana), response (tanggapan), recovery (pemulihan), dan development (pembangunan).

\section{Saran}

Berdasarkan kesimpulan hasil penelitian dan pembahasan penelitian yang sudah disebutkan dan diuraikan di atas, maka peneliti memberikan beberapa saran sebagai masukan yang dapat direkomendasikan kepada pihak-pihak terkait, yaitu sebagai berikut:

1. Pemerintah dan BPBD dapat merealisasikan harapan masyarakat dapat menjalankan manajemen kolaboratif penanggulangan bencana yang dapat memuaskan masyarakat, yaitu dengan cara meningkatkan kolaborasi.

2. Semua elemen meningkatkan partisipasinya dalam berkolaborasi dan bersinergi dalam penanggulangan bencana di Kabupaten Banjarnegara.

3. Masyarakat merubah mindsetnya untuk menjaga alam dan lingkungan, tidak menebang pohon untuk membuka lahan baru. Bila menebang, maka harus menanam kembali.

4. Peneliti selanjutnya dapat melakukan penelitian serupa dengan mengkaji keenam tahapan dalam manajemen bencana yaitu prevention (pencegahan), mitigation (peringatan), preparedness (kesiapsiagaan), disaster impact (dampak bencana), response (tanggapan), recovery (pemulihan), dan development (pembangunan).

\section{DAFTAR PUSTAKA}

Alexander, D. 2014.Principles of emergency planning and management. New york: Oxford University Press.

Ansell, Crish and Gash. 2007. Collaborative Governance In Theory And Practice, Journal Of Public Administration Research And Theory. Vol 1, No. 8. Pp. 543-571.

BPBD Kabupaten Banjarnegara, 2018. Rekapitulasi Kejadian Bencana di Banjarnegara Tahun 2017.

Carter, W. Nick. 1991. Manajemen Penanggulangan Bencana. Manila-Pilipina: Perpustakaan Nasional Data CIP.

Daft. 2010. Era Baru Manajemen. Jilid 1. Edisi ke Sembilan. Jakarta: Salemba Empat.

Gorp, A., Van, F. 2014. Integration of Volunteer andTechnical Communities into the Humanitarian AidSector: Barriers to Collaboration. Proc. ISCRAM,1, 2.

Harley, James \& Blismas, Nick. 2010. An Anatomy of Collaboratuon Within the Online Environment, Dalam Anandarajan, Murugan (ed), e-Research Collaboration: Theory, Techniques and Challengers. Hlm. 15-32. Heidelberg: Springer International Publishing. 
Kristensen, Margit, Kyng, Morten dan Palen. 2006. Participatory Design in Emergency Medical Service: Designing For Future Practice. Paper Presented at The Conference of Human Factors in Computing System-CHI 2006. Montreal: Quebec/Canada.

Kusumasari, Bevaola. 2014. Manajemen Bencana dan Kapabilitas Pemerintah Lokal. Yogyakarta: Gava Media.

Nawawi, Hadari. 2008. Manajemen Sumber Daya Manusia, Yogyakarta : Gadjah Mada University Press.

Nisa, Farichatun. 2014. Manajemen Penanggulangan Bencana Banjir, Puting Beliung, dan Tanah Longsor di Kabupaten Jombang. JKMP (ISSN. 2338-445X), Vol. 2, No. 2, Hal. 103-220.

Noran. O. 2014. Collaborative Disaster Management : An Interdiciplinary Approach. Computers in Industry. Vol. 65, No. 6. Hal. 1032-1040.

Prayogo, 2008. Paradigma Baru, Peran dan Posisi Pengurangan Risiko Bencana dalam Sustainable Development Goals. Prosiding Pertemuan Ilmiah Tahunan Riset Kebencanaan $k e-3$. Bandung: ITB.

Pubita Sasti Fintani. 2013. Studi Evaluasi Implementasi Perda Nomor 2 Tahun 2011 tentang Penyelenggaraan Penanggulangan Bencana di Kabupaten Pemalang. Jurnal Ilmu Pemerintahan. http//www.fisipundip.ac.id.

Purnomo, Hadi dan Ronny Sugiantoro, 2010. Manajemen Bencana. Yogyakarta: Media Pressindo.

Raharja, Sama'un J. 2008. Model Kolaborasi dalam Pengelolaan Daerah Air Sungai Citarum. Disertasi. Universitas Indonesia.

Schrage, Michael. 2015. No More Teams!: Mastering the Dynamics of Creative Collaboration. New York: Dell Publishing Group Inc.

Sekretariat Daerah Kabupaten Banjarnegara, 2017. Indeks Kepuasan Masyarakat per Unsur Pelayanan Kabupaten Banjarnegara Tahun 2017.

Sekretariat Daerah Kabupaten Banjarnegara, 2018. Indeks Kepuasan Masyarakat per Unsur Pelayanan Kabupaten Banjarnegara Tahun 2018.

Suriyanto, 2014. Gubernur Ganjar Fokus Buka Jalur yang Tertimbun Longsor. CNN Indonesia | Senin, 15/12/2014.https://www.cnnindonesia.com/nasional/20141215110833-20-18161/ gubernurganjar-fokus-buka-jalur-yang-tertimbun-longsor

Warto, 2003. Ujicoba Pola Manajemen Penanggulangan Korban Bencana Alam pada Era Otonomi Daerah. Yogyakarta: B2P3KS. 